\title{
PROOXIDANT AND ANTIOXIDANT PROCESSES IN THE LIVER HOMOGENATE OF HEALTHY AND TUMOR-BEARING MICE UNDER THE ACTION OF THIAZOLE DERIVATIVES
}

\author{
Ya. R. SHALAI ${ }^{\square}$, M. V. POPOVYCH ${ }^{1}$, S. M. MANDZYNETS ${ }^{1}$, \\ V. P. HRENIUKH ${ }^{1}$, N. S. FINIUK ${ }^{1,2}$, A. M. BABSKY $Y^{1}$ \\ ${ }^{1}$ Ivan Franko National University of Lviv, Ukraine; \\ ${ }^{2}$ Institute of Cell Biology, National Academy of Sciences of Ukraine, Lviv; \\ 凶e-mail: Yaryna.Shalay@Inu.edu.ua
}

Received: 12 October 2021; Accepted: 17 May 2021

\begin{abstract}
Thiazole derivatives were shown to have toxic effects in vitro on cancer cells of different origin and can be considered as potentially antineoplastic, but their effect on the normal tissues needs to be studied. In this research the newly synthesized thiazole derivatives of $N$-(5-benzyl-1,3-thiazol-2-yl)-3,5-dimethyl-1-benzofuran-2-carboxamide (BF1) and 8-methyl-2-Me-7-[trifluoromethyl-phenylmethyl]-pyrazolo [4,3-e] [1,3] thiazolo [3,2-a] pyrimidin-4 (2H)-one (PP2) were used and their effect on the pro- and antioxidant processes after adding in a 1, 10 and $50 \mu M$ concentrations to the liver homogenate of healthy and NK/Ly lymphoma-bearing mice was estimated. The level of superoxide radical and TBA-active products as well as catalase, SOD and glutathione peroxidase activity were measured. It was shown that superoxide radical and TBA-active products level and catalase activity were significantly higher in the liver of tumor-bearing mice than in the liver of the healthy mice. Neither BF1 no PP2 influenced the studied indices in the liver homogenate of healthy and tumorbearing animals with the exception that PP2 significantly reduced the level of TBA-positive products in both cases. The data obtained showed that the studied thiazole derivatives did not cause severe liver toxicity in both healthy and tumor-bearing mice.
\end{abstract}

Ke ywords: thiazole derivatives, NR/Ly lymphoma, liver, lipid peroxidation, antioxidant system.

A

lmost all the chemotherapy agents have negative side effects when antitumor drugs damage healthy cells, in particular hepatocytes. The liver is the major organ for the detoxification of drugs in human and animals and plays an important role in the excretion of drugs from an organism. Damage of free radical processes and activity of antioxidant system under the effects of antitumor agents may lead to negative side effects.

A cytotoxic effect of investigated thiazole derivatives on cell lines of melanoma, glioblastoma, hepatocarcinoma and leukemia cells has been established $[1,2]$. However, thiazole derivatives did not affect the human pseudonormal embryonic kidney cells and keratinocytes [1]. It was found that investigating compounds changed prooxidant-antioxidant metabolism in Nemeth-Kellner lymphoma (NK/Ly) cells [3]. In particular, the studied thiazole derivatives activated superoxide dismutase and inhibited the catalase and superoxide dismutase activity in lymphoma cells. Presumably, the mechanism of action of these compounds on tumor cells is associated with direct or indirect effects on the enzymes of the antioxidant system [4]. On the other hand, the products of tumor development during its growth in the body can affect the balance of prooxidant and antioxidant processes in other organs, including the liver [5]. Therefore, studying these processes in the liver of tumor-bearing mice is also relevant for planning comprehensive treatment.

To better establish the level of safety of newly synthesized substances, the functional state of liver cells has to be studied. Particularly, the changes in free radicals and antioxidant processes in liver cells

(C) 2021 Shalai Ya. R. et al. This is an open-access article distributed under the terms of the Creative Commons Attribution License, which permits unrestricted use, distribution, and reproduction in any medium, provided the original author and source are credited. 
may suggest the possible mechanisms of negative side effects that often occur after using antitumor drugs. The purpose of this work was to investigate the effect of thiazole derivatives on the level of primary and secondary products of peroxide lipid oxidation (LPO), superoxide radicals and the activity of enzymes of the antioxidant defense in the mouse liver with or without NK/Ly lymphoma and to compare the studied parameters in the liver of healthy mice and tumor-bearing mice.

\section{Materials and Methods}

The study was performed on white (outbred) wildtype male mice (20-30 g) with or without grafted NK/Ly lymphoma. The first group (A), which included healthy mice, served as a positive control. Animals were kept in standard vivarium conditions at constant temperature on a mixed ration. Manipulations with animals were carried out under the principles of the "General Ethical Principles of Experimentation on Animals" approved by the First National Congress on Bioethics (Kyiv, Ukraine, 2001) and "European Convention for the Protection of Vertebrate Animals used for Experimental and Other Scientific Purposes" (Strasbourg, France, 1985).

Mice were anesthetized with chloroform, then decapitated, abdominal dissected and the liver was rapidly excised. The cooled and washed from the blood liver was crushed through a metal press and homogenized in a Potter-Evelheim homogenizer. The liver from mice with lymphoma was extirpated for 28 days after cancer cells inoculation.

The concentration of protein in liver homogenate was determined by the method of Lowry et al. [6]. Thiazole derivatives were synthesized at the Department of Organic Chemistry of Ivan Franko National University of Lviv (the head of a department - Dr. M. Obushak). The steps of synthesis are described in details in our previous publication [1].

$\mathrm{N}$-(5-benzyl-1,3-thiazol-2-yl)-3,5-dimethyl1-benzofuran-2-carboxamide (BF1) and 8-methyl2-Me-7-[trifluoromethyl-phenylmethyl]-pyrazolo[4,3-e]-[1,3]-thiazolo-[3,2-a]-pyrimidin-4(2H)-one) (PP2) were used as a potential antitumor compounds.

The thiazole derivatives were dissolved in the dimethylsulfoxide (DMSO, final concentration 5\%) before their addition to the liver homogenate at final concentrations of 1,10 and $50 \mu \mathrm{M}$. Duration of incubation was $15 \mathrm{~min}$. An equal volume of incubation solution was added to the control samples. The level of lipid hydroperoxides was measured using the method of Myronchyk in the modification of Gavrilov [7] with an absorption wave-length of 480 $\mathrm{nm}$ and was presented in conventional unit/min $\times \mathrm{mg}$ of protein. The level of TBA-positive products was measured by the method of Timirbulatov \& Seleznev [8] with an absorption wavelength of $532 \mathrm{~nm}$ and was expressed in $\mu$ moles/mg of protein. The level of superoxide radical was measured by the method of Denisenko \& Kostenko [9] with an absorption wavelength of $540 \mathrm{~nm}$ and was expressed in nmoles/g×s.

Catalase activity was measured by the method of Korolyuk et al. [10] with an absorption wavelength of $410 \mathrm{~nm}$ and was expressed in nmoles of $\mathrm{H}_{2} \mathrm{O}_{2} / \mathrm{min} \times \mathrm{mg}$ of protein. Superoxide dismutase (SOD) activity was measured by the method of Kostyuk et al [11] and was expressed as unit SOD/mg protein. Glutathione peroxidase activity was measured by the method of Moin [12] with an absorption wave length of $412 \mathrm{~nm}$ and was expressed in $\mathrm{G}-\mathrm{SH} /$ min $\times$ mg of protein.

The MS Excel-2013 program was used for statistical analysis of obtained results. Student's and Wilcoxon coefficients were calculated to assess the significance of the difference between the statistical characteristics of alternative data sets. The difference of the parameters was found to be significant when $P \leq 0.05$.

\section{Results and Discussion}

Fig. 1 shows the changes in the content of primary products of lipid peroxidation in the liver of healthy and tumor-bearing mice under the action of compounds BF1 and PP2. The control levels of hydroperoxides in the liver of healthy mice in both series of experiments did not differ: $2.98 \pm 0.19$ um. units $/ \mathrm{mg}$ protein and $2.72 \pm 0.16 \mathrm{um}$. units $/ \mathrm{mg}$ of protein. In the liver of tumor-bearing mice, control level were higher by $13.0 \%$ and $14.7 \%$, respectively ( $P=0.05$ by Wilcoxon test). However, both substances did not significantly change the levels of hydroperoxides in the liver of healthy and tumorbearing mice.

These results indicate that the tested substances do not affect the level of primary products of lipid peroxidation. Because hydroperoxides rapidly enter into other redox reactions and become a source of secondary products of LPO, the next step of the study was to test the content of second LPO products in the livers of mice in both groups under the action of the tested substances. 

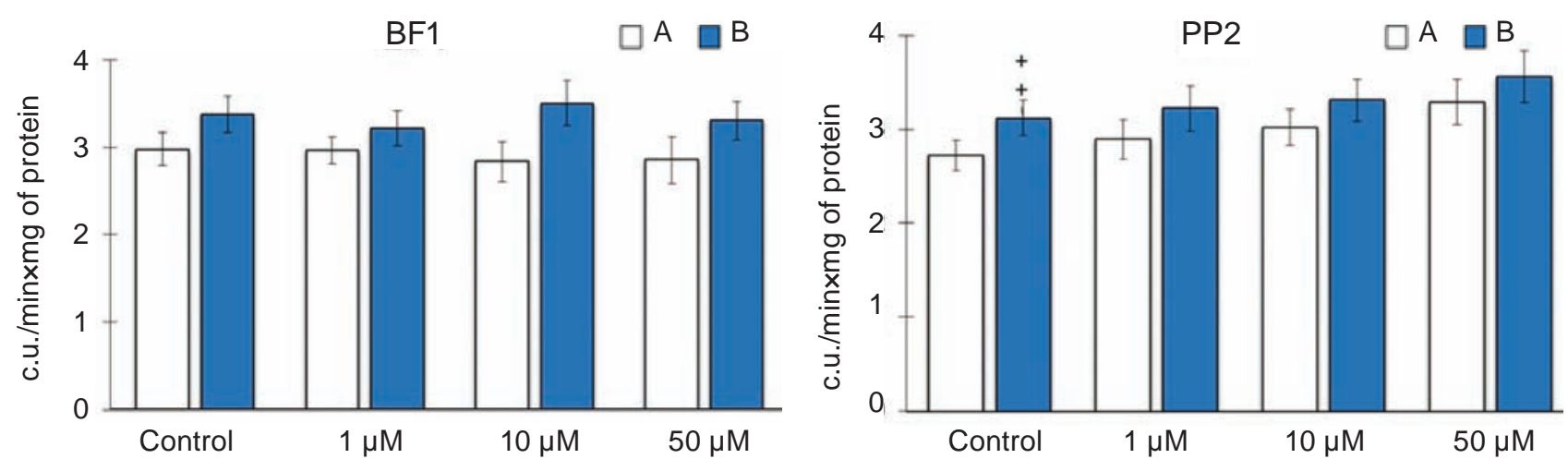

Fig. 1. The level of hydroperoxides in the liver of healthy mice (A) and tumor-bearing mice (B) under the action of thiazole derivatives. ${ }^{\ddagger} P=0.05$ (healthy liver vs. liver of tumor-bearing mice) $M \pm m ; n=5$
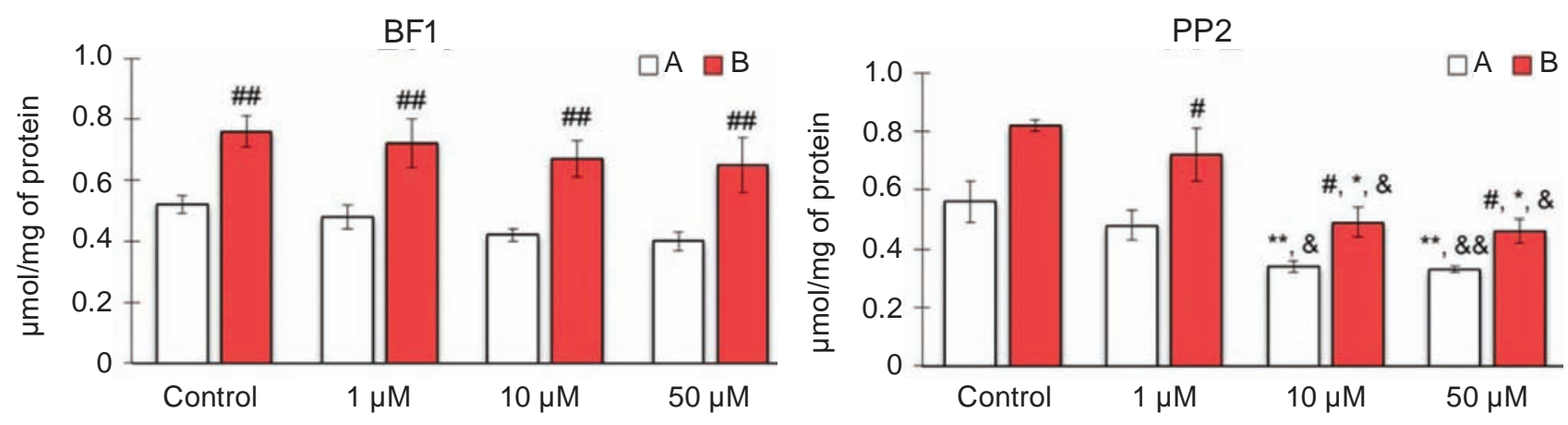

Fig. 2 The level of TBA-positive products in the liver of healthy mice (A) and tumor-bearing mice (B) under the action of thiazole derivatives. ${ }^{*} P<0.05$, ${ }^{* *} P<0.01$ (vs Control), ${ }^{\#} P<0.05,{ }^{* \#} P<0.01$ (healthy vs tumorbearing mice), ${ }^{\circledR} P<0.05$, ${ }^{\&} \& P<0.01$ (vs $\left.1 \mu \mathrm{M}\right)$

Fig. 2 shows the changes in the content of TBA-positive products in the liver of healthy mice (A) and mice with lymphoma (B) under the action of the tested compounds. Control levels of TBApositive products in the liver of healthy mice in two series of experiments were: $0.52 \pm 0.03 \mu \mathrm{mol} /$ $\mathrm{mg}$ protein and $0.56 \pm 0.07 \mu \mathrm{mol} / \mathrm{mg}$ protein. In the liver of tumor-bearing mice, control levels of TBApositive products were higher by $46.2 \%$ ( $\# P<0.067$ ) and $46.4 \%$ ( $\# P<0.001$ ), respectively, compared to healthy mice. It was found that the level of TBApositive products in the livers of mice of both groups did not change under the action of BF1 at all three concentrations. Under the action of PP2 at concentrations of 10 and $50 \mu \mathrm{m}$, the level of this product significantly $(* P<0.01)$ decreased by $39.3 \%$ and $41 \%$ (in the liver of a healthy mouse) and by $40.2 \%$ and $43.9 \%$ (in the liver of a tumor-bearing mouse), respectively. One-factor analysis established a dosedependent manner of these effects.
It was found that with the development of Nemeth-Kellner lymphoma, the level of TBA-positive products in the liver of mice increases significantly. However, thiazole derivatives not only do not increase the level of TBA-positive products (BF1), but also reduce it (PP2).

Since the development of the tumor significantly changes the redox balance in the cells, we should expect a change in the level of free radicals. Therefore, the content of superoxide radicals in the liver cells of healthy mice and tumor-bearing mice was studied (Fig. 3). Control levels of superoxide radicals in the liver of healthy mice were: $0.16 \pm 0.01 \mathrm{nmol} /$ $\mathrm{g} \times \mathrm{S}$ and $0.19 \pm 0.01 \mathrm{nmol} / \mathrm{g} \times \mathrm{s}$. In the liver of tumorbearing mice, the control levels of the superoxide radicals were higher by $50 \%(\# P<0.01)$ and $37 \%$ (\#P<0.01), respectively, compared to healthy mice. It was found that BF1 and PP2 in all studied concentrations did not change the level of superoxide radicals in the liver cells of healthy mice and tumorbearing mice. 

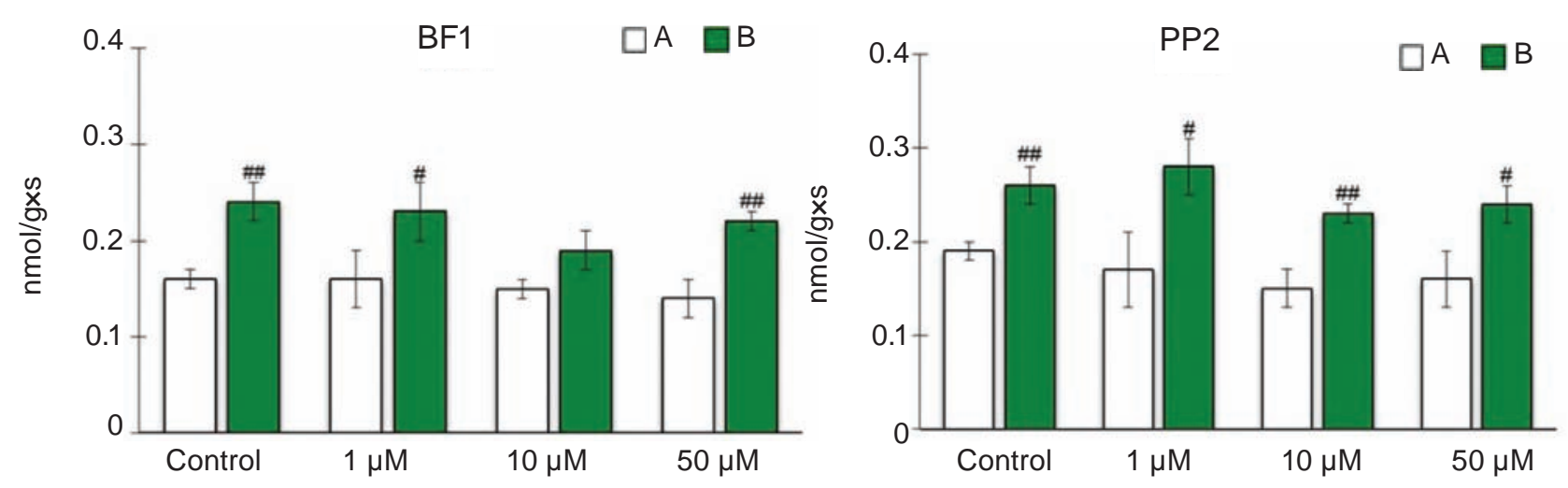

Fig. 3 The level of superoxide radical in the liver of healthy mice (A) and tumor-bearing mice (B) under the action of thiazole derivatives. ${ }^{\#} P<0.05,{ }^{\# \#} P<0.01$ (healthy vs tumor-bearing mice)

Fig. 4 shows the changes in the SOD activity under the action of BF1 and PP2. Control levels of the enzyme activity in the liver of healthy mice in two series of experiments were $5.43 \pm 1.06$ units active/min $\times$ mg protein and $5.32 \pm 0.63$ units active/ min $\times$ mg protein, respectively. In the liver of tumor-bearing mice, control levels of SOD activity were $5.73 \pm 0.43$ units active/min $\times$ mg protein and $6.02 \pm 0.58$ u.a. $/ \mathrm{min} \times \mathrm{mg}$ protein. Under the action of both tested compounds, the enzyme activity in the liver of healthy mice and tumor-bearing mice was not changed.

Because $\mathrm{H}_{2} \mathrm{O}_{2}$ is the product of SOD activity, the normal functioning of other enzymes that neutralize hydrogen peroxide is important. Therefore, we tested the effect of the studied derivatives on the activity of CAT and GPO.

Fig. 5 shows the changes in catalase activity under the action of BF1 and PP2. Control levels of enzyme activity in the liver of healthy mice were $7.33 \pm 0.8 \mathrm{nmol} \mathrm{H}_{2} \mathrm{O}_{2} / \mathrm{min} \times \mathrm{mg}$ protein and $7.21 \pm 0.28 \mathrm{nmol} \mathrm{H}_{2} \mathrm{O}_{2} /$ min $\times$ mg protein, respectively. In the liver of tumor-bearing mice, control levels of CAT activity were higher by $32 \%(P<0.01)$ and $30 \%$ $(P<0.01)$, respectively, compared to healthy mice. However, both compounds did not change the activity of the enzyme.

Fig. 6 shows the changes in glutathione peroxidase activity under the action of BF1 and PP2. Control levels of GPO activity in the liver of healthy mice of both groups were $6.23 \pm 0.83 \mathrm{nmol} \mathrm{GSH} / \mathrm{min} \times \mathrm{mg}$ protein and $5.86 \pm 0.68 \mathrm{nmol} \mathrm{GSH} / \mathrm{min} \times \mathrm{mg}$ protein. In the liver of tumor-bearing mice, the control levels of GPO activity were $5.11 \pm 0.92 \mathrm{nmol} \mathrm{GSH} / \mathrm{min} \times \mathrm{mg}$ protein and $5.02 \pm 0.68 \mathrm{nmol} \mathrm{GSH} / \mathrm{min} \times \mathrm{mg}$ protein. Under the action of both test compounds, the activity of the enzyme in the liver of healthy mice and tumor-bearing mice did not change.

Many chemotherapeutic drugs have a low selective effect and therefore provoke significant side
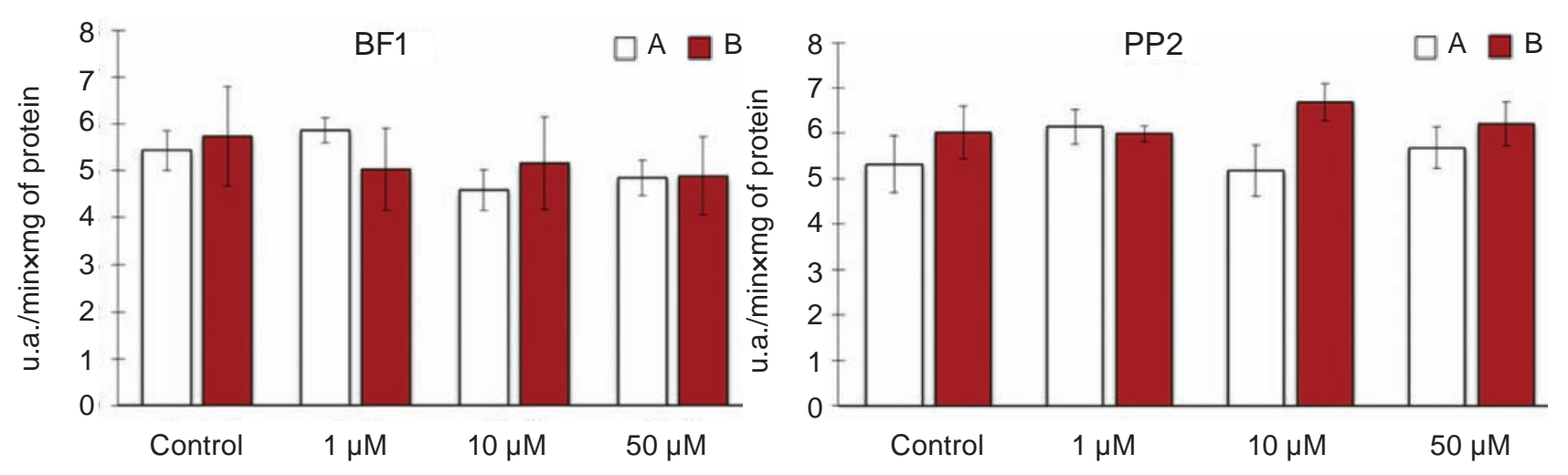

Fig. 4. The level of activity of SOD in the liver of healthy mice (A) and tumor-bearing mice (B) under the action of thiazole derivatives 

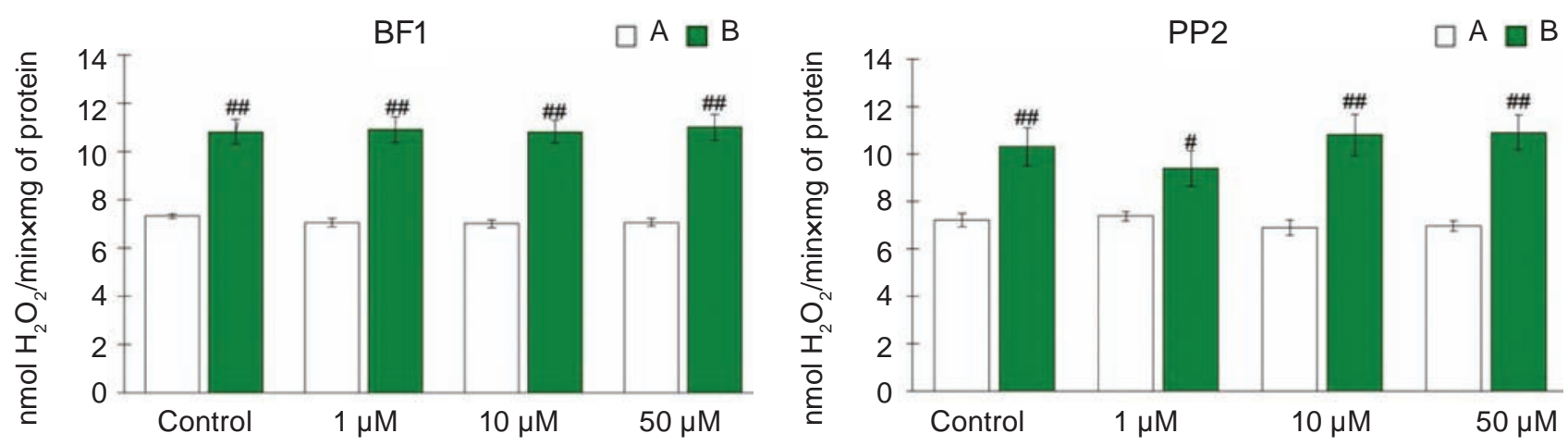

Fig. 5. The level of activity of CAT in the liver of healthy mice (A) and tumor-bearing mice (B) under the action of thiazole derivatives. ${ }^{\#} \mathrm{P}<0.05,{ }^{\# \#} \mathrm{P}<0.01$ (healthy vs tumor-bearing mice)
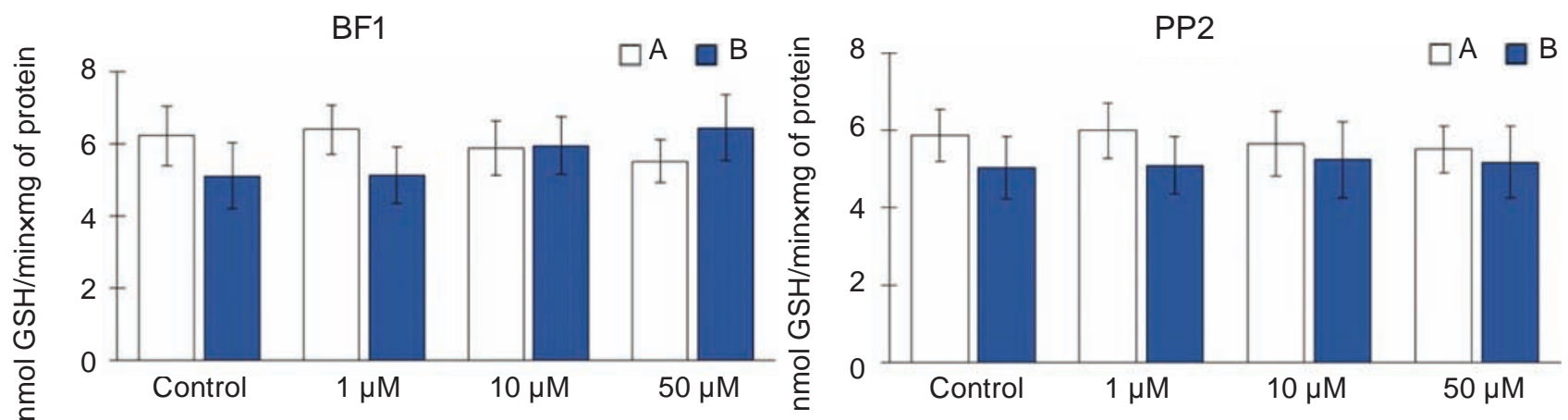

Fig. 6. The level of activity of GPO in the liver of healthy mice (A) and tumor-bearing mice (B) under the action of thiazole derivatives

effects. Particularly dangerous are the side effects of cytostatics, such as cardiotoxicity, hepatotoxicity, neurotoxicity, nephrotoxicity and effects on the immune system. Exposure to anticancer substances can significantly damage the functioning of the body.

With the development of the tumor, the resources of the physiological antioxidant system are depleted [13]. In this status, one could expect a decrease in the antitumor reactivity of the organism, which is a prerequisite for further tumor growth. However, we found that in the liver of tumor-bearing mice, the activity of antioxidant enzymes is balanced, when both SOD activity and CAT activity increase by $13 \%$ and $30 \%$, respectively. Such changes in the activity of enzymes in the liver of mice with lymphoma may indicate possible protective mechanisms that are activated in the liver under conditions of intensification of free radical oxidation.

It was found that under the action of substances BF1 and PP2, the content of primary products of LPO, as well as the activity of antioxidant enzymes, did not change. Only the content of TBA-positive products was significantly reduced by the action of
PP2 at concentrations of 10 and $50 \mu \mathrm{m}$. One-factor analysis established a dose-dependent manner of these effects. There is a trifluoromethyl group in the structure of PP2, which can increase the permeability of this compound in the cell and determine its high activity [14]. Therefore, the decrease in the level of TBA-positive products may be associated with the action of a trifluoromethyl group in the composition of the compound. These results confirm the hypothesis of the probable interaction of this compound with reactive oxygen species and the possible antioxidant properties in the liver. On the other hand, BF1 does not contain a trifluoromethyl group, but contains benzofuran, which causes the cytotoxic properties of this substance against tumor cells [1-3], but does not affect the pro- and antioxidant processes in nontumor liver cells. Therefore, the test compounds are different in structure and differently affect the content of LPO products, but both substances do not affect the activity of enzymes of the antioxidant system.

During the development of tumors, systemic damage to the body by the products of tumor decay and changes in the redox balance in tissues and or- 
gans are expected. For example, Demkiv et al. [13] found that with the development of adenocarcinoma of the colon in rats, the level of LPO products in the pancreas significantly increased. The liver is also an organ where metastases often occur because one of the most dangerous ways for tumor cells to spread is portal circulation. Metastases can also occur in a lymphogenic way, when cancer cells, in particular carcinomas, spread in the body through lymphatic vessels to regional lymph nodes.

Interestingly, the LPO processes in our studies differed in the liver of control healthy mice and the liver of tumor-bearing mice. It was found that in the liver of mice with lymphoma, the level of TBApositive products was higher by more than $45 \%$ than in the liver of control mice. Thus, the development of lymphoma provokes an increase in the number of secondary products of LPO in the liver, as a consequence of increasing levels of reactive oxygen species. Therefore, thiazole derivatives do not cause severe liver toxicity in both healthy and tumor-bearing mice.

Conclusions. It was investigated that in the liver of tumor-bearing mice, the content of LPO products and the activity of antioxidant enzymes were significantly higher, which may be a consequence of tumor development in the body of a sick mouse. Substances BF1 and PP2 are different in their structure, but none of the substances affected the activity of enzymes of the antioxidant system in the liver of mice of both groups. It was found that the substance PP2 dose-dependently reduced the level of secondary products of LPO in the liver of healthy mice and tumor-bearing mice, while under the action of BF1, this parameter did not change. This may be due to the presence in the structure of the substance PP2 trifluoromethyl group, which determines the toxic properties of the substance.

Conflict of interest. The authors have completed the Unified Conflicts of Interest form at http:// ukrbiochemjournal.org/wp-content/uploads/2018/12/ coi_disclosure.pdf and declare no conflict of interest.

Funding. This research was supported by the Ministry of Education and Science of Ukraine grant (registration number 0119U002201).

\section{ПРООКСИДАНТНІ ТА \\ АНТИОКСИДАНТНІ ПРОЦЕСИ \\ У ГОМОГЕНАТІ ПЕЧІНКИ \\ ЗДОРОВИХ МИШЕЙ ТА МИШЕЙ- \\ ПУХЛИНОНОСІїв 3А ДІї \\ ПОХІДНИХ ТІАЗОЛУ}

\author{
Я. Р. Шалай \\ С. М. Мандзинеиьь ${ }^{1}$ В. П. Гренюх ${ }^{1}$, \\ Н. С. Фінюк ${ }^{1,2}$, А. М. Бабський \\ ${ }^{1}$ Львівський національний університет \\ імені Івана Франка, Україна; \\ ${ }^{2}$ Інститут біології клітини НАН України, Львів; \\ 凶e-mail: Yaryna.Shalay@lnu.edu.ua
}

Похідні тіазолу in vitro виявляють токсичну дію на злоякісні клітини різного походження та можуть розглядатись як потенційно антинеопластичні, проте їх вплив на нормальні тканини потребує дослідження. У роботі було використано новосинтезовані похідні тіазолу $\mathrm{N}$-(5-бензил-1,3-тіазол2-іл)-3,5-диметил-1бензофуран-2-карбоксамід (BF1) та 8-метил2-Ме-7-[трифлуорометил-фенілметил] піразоло[4,3-е][1,3]тіазоло[3,2-а]піримідин4(2Н)-он (РP2) та оцінено їх вплив на про- та антиоксидантні процеси після додавання у 1,10 та $50 \mu \mathrm{M}$ концентраціях до гомогенату печінки здорових мишей та мишей 3 прищепленою NK/ Ly лімфомою. У гомогенатах печінки оцінювали рівень супероксидрадикалу та ТБК-активних продуктів, а також активність каталази, СОД та глутатіон пероксидази. Показано, що рівень супероксидрадикалу, ТБК-активних продуктів та активність каталази були значно вищими в печінці мишей-пухлиноносіїв, аніж у печінці здорових мишей. Встановлено, що сполуки ВF1 та PР2 не впливали на величину досліджуваних показників у печінці як мишей-пухлиноносіїв, так і контрольних мишей за винятком того, що сполука РР2 спричинювала значне зниження рівня ТБК-активних продуктів в обох випадках. Одержані результати вказують на те, що досліджувані похідні тіазолу не чинять виразної гепатотоксичної дії на організм здорових мишей та мишей-пухлиноносіїв.

К л юч о в і слов в: похідні тіазолу, лімфома NR/Ly, печінка, пероксидне окислення ліпідів, антиоксидантна система. 


\section{References}

1. Finiuk NS, Hreniuh VP, Ostapiuk YuV, Matiychuk VS, Frolov DA, Obushak MD, Stoika RS, Babsky AM. Antineoplastic activity of novel thiazole derivatives. Biopolym Cell. 2017; 33(2): 135-146.

2. Finiuk N, Klyuchivska O, Ivasechko I, Hreniukh V, Ostapiuk Yu, Shalai Ya, Panchuk R, Matiychuk V, Obushak M, Stoika R, Babsky A. Proapoptotic effects of novel thiazole derivative on human glioma cells. Anticancer Drugs. 2019; 30(1): 27-37.

3. Shalai YaR, Mandzynets SM, Hreniukh VP, Finiuk NS, Babsky AM. Free-radical processes in NK/Ly lymphoma cells and hepatocytes under the effect of thiazole derivative. Bull Probl Biol Med. 2018; 1.2(143): 234-238. (In Ukrainian).

4. Shalai YaR, Popovych MV, Kulachkovskyy OR, Hreniukh VP, Mandzynets SM, Finiuk NS, Babsky AM. Effect of novel 2-amino5-benzylthiazole derivative on cellular ultrastructure and activity of antioxidant system in lymphoma cells. Studia Biologica. 2019; 13(1): 51-60.

5. Bazinet L, Doyen A. Antioxidants, mechanisms, and recovery by membrane processes. Crit Rev Food Sci Nutr. 2017; 57(4): 77-700.

6. Lowry OH, Rosebrough NJ, Farr AL, Randall RJ. Protein measurement with the Folin phenol reagent. J Biol Chem. 1951; 193(1): 265-275.

7. Gavrilov VB, Mishkorudnaya MI. Spectrophotometric determination of the content of lipid hydroperoxides in blood plasma. Lab Delo. 1983;(3): 33-35.
8. Timirbulatov RA, Seleznev EI. Method for increasing the intensity of free radical oxidation of lipid-containing components of the blood and its diagnostic significance. Lab Delo. 1981; (4): 209-211. (In Russia).

9. Denisenko SV, Kostenko VA. Changes in the production of reactive oxygen species in the testes of white rats under conditions of chronic intoxication with sodium nitrate. Modern Probl Toxicol. 2002; (4): 44-46. (In Russian).

10. Korolyuk MA, Ivanova LI, Mayorova IH, Tokaryev VYe. A method of determining catalase activity. Lab Delo. 1988; (1): 16-19. (In Russian).

11. Kostyuk VA, Potapovich AI, Kovaleva ZnV. Kostiuk VA, Potapovich AI, Kovaleva ZhV. A simple and sensitive method of determination of superoxide dismutase activity based on the reaction of quercetin oxidation. Vopr Med Khim. 1990; 36(2): 88-91. (In Russian).

12. Moin VM. A simple and specific method for determining glutathione peroxidase activity in erythrocytes. Lab Delo. 1986; (12): 724-727. (In Russian).

13. Demkiv IY, Lisnychuk NY, Soroka YV, Chykhyra OV. Redox balance in white rats' spleen under induced carcinogenesis. Med Clin Chem. 2016; 3): 38-42. (In Ukrainian).

14. Rahmouni A, Souiei S, Belkacem MA, Romdhane A, Bouajila J, Ben Jannet $\mathrm{H}$. Synthesis and biological evaluation of novel pyrazolopyrimidines derivatives as anticancer and anti-5-lipoxygenase agents. Bioorg Chem. 2016; 66: 160-168. 